\title{
IMPLEMENTASI PERATURAN MAHKAMAH AGUNG REPUBLIK INDONESIA NOMOR 1 TAHUN 2016 TENTANG PROSEDUR MEDIASI DI PENGADILAN (Study Putusan Pengadilan Agama Rantauprapat No. No.487/Pdt.G/2020/PA-RAP Jo Putusan Pengadilan Tinggi Medan No.73/Pdt.G/2020/PTA-MDN)
}

\author{
Muhammad Yusuf Siregar \\ Fakultas Hukum Universitas Labuhanbatu \\ Email : Siregaryusuf90@yahoo.co.id
}

\begin{abstract}
This study aims to analyze the legal aspects of the implementation of the Supreme Court Regulation No. 1 of 2016 on Mediation Procedures in Courts (Study of Rantauprapat Religious Court Decision No. 487 / Pdt.G / 2020 / PA-RAP Jo Medan High Court Decision No. 73 / Pdt.G / 2020 / PTA-MDN. This research is Normative Empirical, which is research by looking at conditions in the field by linking the source of laws and regulations in force in the Republic of Indonesia. The benefits that will be received from the results of this study are to find out and analyzing the legal position of the Supreme Court Regulation Number 1 of 2016 concerning Mediation Procedures in Courts and To find out and analyze the Implementation of the Supreme Court Regulation Number 1 of 2016 concerning Mediation Procedures in Courts in the Rantauprapat Religious Court Decision No.487 / Pdt .G / 2020 / PA-RAP Jo Medan High Court Decision No.73 / Pdt.G / 2020 / PTA-MDN. The results of the research show that the provisions of the Regulation of the Supreme Court of the Republic of Indonesia Number 1 of 2008 and / or Regulation of the Supreme Court of the Republic of Indonesia Number 1 of 2016 concerning Mediation Procedures in Courts in article 02 paragraph 04 states that "Judges in consideration of the decision of a case must state that the case concerned has strived for peace through Mediation by stating the name of the Mediator for the case concerned. The position of Mediation as stated in the Regulation of the Supreme Court of the Republic of Indonesia Number 1 of 2016 is one of the steps that must be taken in carrying out the Judicial system which is based on the decision of the Medan High Court Panel of Judges declaring that to completely reject the Plaintiff's Lawsuit with the Consideration that the case has been taken through the Mediation route although not maximally and His legal consideration is that the position of the witnesses presented by the Plaintiff is a witness who did not see the Plaintiff and Defendant fighting, but only told the story of the Plaintiff.
\end{abstract}

Keywords: Implementation, Procedure, Mediation

\begin{tabular}{l} 
ABSTRAK \\
Penelitian ini bertujuan untuk menganalis aspek hukum Implementasi Peraturan Mahkamah Agung \\
Republik Indonesia Nomor 1 Tahun 2016 Tentang Prosedur Mediasi di Pengadilan (Study Putusan \\
Pengadilan Agama Rantauprapat No. No.487/Pdt.G/2020/PA-RAP Jo Putusan Pengadilan Tinggi \\
Medan No.73/Pdt.G/2020/PTA-MDN. Penelitian ini bersifat Normatif Empiris yakni penelitian \\
dengan melihat kondisi yang ada dilapangan dengan mengkaitkan sumber hukum peraturan - \\
peraturan yang berlaku di Negara Republik Indonesia. Manfaat yang akan diterima dari hasil \\
penelitian ini adalah Untuk mengetahui dan menganalisis kedudukan hukum Peraturan Mahkamah \\
Agung Republik Indonesia Nomor 1 Tahun 2016 Tentang Prosedur Mediasi di Pengadilan serta \\
Untuk mengetahui dan menganalisis Implementasi Peraturan Mahkamah Agung Republik Indonesia \\
Nomor 1 Tahun 2016 Tentang Prosedur Mediasi di Pengadilan dalam Putusan Pengadilan Agama \\
Rantauprapat No. No.487/Pdt.G/2020/PA-RAP Jo Putusan Pengadilan Tinggi Medan \\
No.73/Pdt.G/2020/PTA-MDN. Hasil penelitian menunjukkan bahwa ketentuan Peraturan \\
monan \\
\hline Jurnal Ilmiah “Advokasi" Vol 08 No. 02 September 2020
\end{tabular}


Mahkamah Agung Republik Indonesia Nomor 1 Tahun 2008 dan atau Peraturan Mahkamah Agung Republik Indonesia Nomor 1 Tahun 2016 Tentang Prosedur Mediasi di Pengadilan pada pasal 02 ayat 04 mengemukakan bahwa "Hakim dalam Pertimbangan Putusan perkara Wajib menyebutkan bahwa perkara yang bersangkutan telah diupayakan perdamaian melalui Mediasi dengan menyebutkan nama Mediator untuk perkara yang bersangkutan. Kedudukan Mediasi sebagaimana Peraturan Mahkamah Agung Republik Indonesia Nomor 1 Tahun 2016 adalah salah satu langkah yang harus ditempuh dalam menjalankan sistem Peradilan yang mana berdasarkan Putusan Majelis Hakim Pengadilan Tinggi Medan menyatakan Menolak Gugatan Penggugat seluruhnya dengan Pertimbangan Perkara tersebut telah ditempuh jalur Mediasi walaupun tidak secara maksimal serta pertimbangan hukumnya bahwa kedudukan saksi yang dihadirkan oleh Penggugat adalah saksi yang sama sekali tidak melihat antara Penggugat dan Tergugat bertengkar namun hanya menceritakan cerita dari Penggugat.

\section{Kata Kunci : Implementasi, Prosedur, Mediasi}

\section{PENDAHULUAN}

\subsection{Latar Belakang}

Mediasi adalah upaya penyelesaian konflik dengan melibatkan pihak ketiga yang netral, yang tidak memiliki kewenangan mengambil keputusan yang membantu pihakpihak yang bersengketa mencapai penyelesaian (solusi) yang diterima oleh kedua belah pihak.

Mediasi merupakan proses negosiasi pemecahan masalah, dimana pihak luar yang tidak memihak (impartial) bekerjasama dengan pihak yang bersengketa untuk mencari kesepakatan bersama. Mediator tidak berwenang untuk memutus sengketa, tetapi hanya membantu para pihak untuk menyelesaikan persoalan-persoalan yang dikuasakan kepadanya.

Dari pengertian di atas dapat diketahui bahwa yang dimaksud dengan mediasi adalah upaya menyelesaikan sengketa para pihak dengan kesepakatan bersama melalui mediator yang bersikap netral dan tidak membuat keputusan atau kesimpulan bagi para pihak tetapi menunjang fasilitator untuk terlaksananya dialog antar pihak dengan suasana keterbukaan, kejujuran, dan tukar pendapat untuk mencapai mufakat.

Dalam ketentuan Penjelasan pasal 3 ayat 1 UU No. 14 tahun 1970 mengemukakan bahwa: "Semua peradilan di seluruh wilayah Republik Indonesia adalah Peradilan Negara dan ditetapkan dengan undang-undang”. Pasal ini mengandung arti, bahwa di samping Peradilan Negara, tidak diperkenankan lagi adanya peradilanperadilan yang dilakukan oleh bukan Badan Peradilan Negara. Penyelesaian perkara di luar pengadilan atas dasar perdamaian atau melalui wasit tetap diperbolehkan.

Dalam ketentuan PERMA No. 1 tahun 2008 jo Peraturan Mahkamah Agung Republik Indonesia Nomor 1 Tahun 2016 Tentang Prosedur Mediasi Di Pengadilan dikemukakan bahwa Hakim wajib menjelaskan prosedur mediasi kepada para pihak yang bersengketa atau kuasanya, dan mendorong para pihak untuk berperan langsung atau aktif dalam proses mediasi. 
Selanjutnya hakim sidang menunda proses persidangan perkara tersebut untuk memberi kesempatan kepada para pihak menempuh proses mediasi. Dalam praktek selama ini sebelum berlakunya Perma No. 1 tahun 2008 jo Peraturan Mahkamah Agung Republik Indonesia Nomor 1 Tahun 2016 Tentang Prosedur Mediasi Di Pengadilan, sidang ditunda selama satu atau dua minggu saja, namun dalam berlakunya Perma yang mengatur tentang lamanya proses mediasi paling lama 40 hari kerja, sejak mediator dipilih oleh para pihak atau ditunjuk oleh ketua majelis hakim, maka hakim akan menyesuaikan penundaan sidang sesuai dengan pasal- pasal tersebut, dengan ketentuan dapat dipercepat apabila tercapai kesepakatan secara dini atau mediasi gagal, dan tidak dimungkinkan lagi dilanjutkan proses mediasi, atau laporan tertulis dari mediator kepada hakim sidang. Kemudian pada hari sidang tersebut, atau dalam waktu paling lama dua hari kerja berikutnya, para pihak atau kuasa hukumnya wajib berunding untuk memilih mediator dari daftar mediator yang dimiliki oleh Pengadilan.

Jika dalam waktu dua hari kerja para pihak atau kuasa hukum mereka bersepakat tentang pilihan Mediator yang dikehendaki, para pihak wajib melaporkan kepada ketua Majelis Hakim, dan Ketua Majelis Hakim segera memberitahukan kepada mediator terpilih untuk menjelaskan tugas. Demikian pula sebaliknya, jika dalam waktu yang sama, para pihak tidak berhasil memilih mediator yang dikehendaki, maka kegagalan tersebut harus segera diberitahukan kepada ketua majelis, dan ketua majelis berwenang untuk menunjuk hakim bukan pemeriksa pokok perkara yang bersertifikat pada pengadilan yang sama untuk menjalankan fungsi Mediator dengan menerbitkan Penetapan.

Proses hukum sebagaimana yang telah disebutkan diatas adalah langkah hukum yang harus ditempuh untuk memenuhi ketentuan sebagaimana yang telah diamanatkan berdasarkan Ketentuan Peraturan Mahkamah Agung Republik Indonesia Nomor 01 Tahun 2008 Tentang Prosedur Mediasi Di Pengadilan pada pasal 02 ayat 04 mengemukakan bahwa "Hakim dalam Pertimbangan Putusan perkara Wajib menyebutkan bahwa perkara yang bersangkutan telah diupayakan perdamaian melalui Mediasi dengan menyebutkan nama Mediator untuk perkara yang bersangkutan”.

Selanjutnya berdasarkan ketentuan Pasal 03 ayat 1 Peraturan Mahkamah Agung Republik Indonesia Nomor 1 Tahun 2016 Tentang Prosedur Mediasi Di Pengadilan mengemukakan bahwa : "Setiap Hakim, Mediator, Para Pihak dan/atau Kuasa Hukum $\underline{\text { Wajib }}$ mengikuti Prosedur Penyelesaian Sengketa melalui Mediasi”

Selanjutnya Pasal 03 ayat 02 Peraturan Mahkamah Agung Republik Indonesia Nomor 1 Tahun 2016 Tentang Prosedur Mediasi Di Pengadilan mengemukakan pula bahwa "Hakim Pemeriksa Perkara dalam pertimbangan putusan wajib menyebutkan Jurnal Ilmiah "Advokasi" Vol 08 No. 02 September 2020 
bahwa perkara telah diupayakan perdamaian melalui Mediasi dengan menyebutkan nama Mediator".

Bahwa dalam prakteknya Majelis Hakim dalam memutuskan perkara pada Pengadilan Agama Rantauprapat No.487/Pdt.G/2020/PARAP yang sama sekali Tidak memberikan kesempatan untuk Melakukan Mediasi / menempuh Prosedur Mediasi sangat jelas telah melakukan Pelanggaran terhadap Ketentuan Pasal 130 HIR dan atau Pasal 154 Rbg yang mengakibatkan Putusan Batal Demi Hukum.

Namun kenyataannya Putusan Hukum Pengadilan Agama Rantauprapat No.487/Pdt.G/2020/PA-RAP Bertanggal 02 April 2020, yang amar putusannya berbunyi sebagai berikut Mengadili dengan Mengabulkan Gugatan Penggugat untuk seluruhnya, Menjatuhkan Talaq Satu Ba'in Sughro Tergugat Terhadap Penggugat serta Membebankan Kepada penggugat untuk membayar biaya perkara sejumlah Rp. 396.000,- (tiga ratus sembilan puluh enam ribu rupiah);

Dengan demikian, merujuk kepada salah satu contoh kasus diatas, maka penting untuk dilakukan penelitian dan pengkajian secara hukum tentang Implementasi Peraturan Mahkamah Agung Republik Indonesia Nomor 1 Tahun 2016 Tentang Prosedur Mediasi di Pengadilan (Study Putusan Pengadilan Agama Rantauprapat No. No.487/Pdt.G/2020/PARAP Jo Putusan Pengadilan Tinggi Medan No.73/Pdt.G/2020/PTA-MDN.

\subsection{Perumusan Masalah}

Berdasarkan pemaparan uraian yang dikemukakan diatas, menjadi pokok permasalahan yang ingin diteliti dan di bahas dalam penulisan ini adalah sebagai berikut:

1. Bagaimana kedudukan hukum Peraturan Mahkamah Agung Republik Indonesia Nomor 1 Tahun 2016 Tentang Prosedur Mediasi di Pengadilan?

2. Bagaimanakah Implementasi Peraturan Mahkamah Agung Republik Indonesia Nomor 1 Tahun 2016 Tentang Prosedur Mediasi di Pengadilan dalam Putusan Pengadilan Agama Rantauprapat No. No.487/Pdt.G/2020/PA-RAP Jo Putusan Pengadilan Tinggi Medan No.73/Pdt.G/2020/PTA-MDN?

\subsection{Tujuan Penelitian}

Sesuai dengan rumusan masalah yang telah dikemukakan maka yang menjadi tujuan dalam penelitian ini adalah sebagai berikut:

1. Untuk mengetahui dan menganalisis kedudukan hukum Peraturan Mahkamah Agung Republik Indonesia Nomor 1 Tahun 2016 Tentang Prosedur Mediasi di Pengadilan.

2. Untuk mengetahui dan menganalisis Implementasi Peraturan Mahkamah Agung Republik Indonesia Nomor 1 Tahun 2016 Tentang Prosedur Mediasi di Pengadilan dalam Putusan Pengadilan Agama Rantauprapat No. 
No.487/Pdt.G/2020/PA-RAP Jo

Putusan Pengadilan Tinggi Medan

No.487/Pdt.G/2020/PTA-MDN.

\section{PEMBAHASAN}

\subsection{Kedudukan hukum Peraturan Mahkamah Agung Republik Indonesia Nomor 1 Tahun 2016 Tentang Prosedur Mediasi di Pengadilan.}

Mediasi merupakan cara penyelesaian sengketa secara damai yang tepat, efektif, dan dapat membuka akses yang lebih luas kepada Para Pihak untuk memperoleh penyelesaian yang memuaskan serta berkeadilan.

Dalam rangka reformasi birokrasi Mahkamah Agung Republik Indonesia yang berorientasi pada visi terwujudnya badan peradilan indonesia yang agung, salah satu elemen pendukung adalah Mediasi sebagai instrumen untuk meningkatkan akses masyarakat terhadap keadilan sekaligus implementasi asas penyelenggaraan peradilan yang sederhana, cepat, dan berbiaya ringan.

Ketentuan hukum acara perdata yang berlaku, Pasal 154 Reglemen Hukum Acara untuk Daerah Luar Jawa dan Madura (Reglement Tot Regeling Van Het Rechtswezen In De Gewesten Buiten Java En Madura, Staatsblad 1927:227) dan Pasal 130 Reglemen Indonesia yang diperbaharui (Het Herziene Inlandsch Reglement, Staatsblad 1941:44) mendorong Para Pihak untuk menempuh proses perdamaian yang dapat didayagunakan melalui Mediasi dengan mengintegrasikannya ke dalam prosedur berperkara di Pengadilan.

Prosedur Mediasi di Pengadilan menjadi bagian hukum acara perdata dapat memperkuat dan mengoptimalkan fungsi lembaga peradilan dalam penyelesaian sengketa.

Lahirnya Peraturan Mahkamah Agung Republik Indonesia Nomor 1 Tahun 2008 tentang Prosedur Mediasi di Pengadilan belum optimal memenuhi kebutuhan pelaksanaan Mediasi yang lebih berdayaguna dan mampu meningkatkan keberhasilan Mediasi di Pengadilan; f. bahwa berdasarkan pertimbangan sebagaimana dimaksud dalam huruf $a$, huruf $b$, huruf $c$, huruf $d$ dan huruf e, sehingga perlu menyempurnakan Peraturan Mahkamah Agung tentang Prosedur Mediasi di Pengadilan sehingga lahirlah Peraturan Mahkamah Agung Republik Indonesia Nomor 1 Tahun 2016 Tentang Prosedur Mediasi di Pengadilan.

Lahirnya Peraturan Mahkamah Agung Republik Indonesia Nomor 1 Tahun 2008 dan atau Peraturan Mahkamah Agung Republik Indonesia Nomor 1 Tahun 2016 Tentang Prosedur Mediasi di Pengadilan tentang Prosedur Mediasi di Pengadilan adalah berlandaskan dengan Undang-Undang Nomor 3 Tahun 2009 tentang Perubahan Kedua Atas Undang-Undang Nomor 14 Tahun 1985 tentang Mahkamah Agung serta UndangUndang Nomor 48 Tahun 2009 tentang Kekuasaan Kehakiman. 
Dalam ketentuan Peraturan Mahkamah Agung Republik Indonesia Nomor 1 Tahun 2008 dan atau Peraturan Mahkamah Agung Republik Indonesia Nomor 1 Tahun 2016 Tentang Prosedur Mediasi di Pengadilan pada pasal 02 ayat 04 mengemukakan bahwa "Hakim dalam Pertimbangan Putusan perkara Wajib menyebutkan bahwa perkara yang bersangkutan telah diupayakan perdamaian melalui Mediasi dengan menyebutkan nama Mediator untuk perkara yang bersangkutan".

Selanjutnya berdasarkan ketentuan Pasal 03 ayat 1 Peraturan Mahkamah Agung Republik Indonesia Nomor 1 Tahun 2016 Tentang Prosedur Mediasi Di Pengadilan mengemukakan bahwa : " Setiap Hakim, Mediator, Para Pihak dan/atau Kuasa Hukum

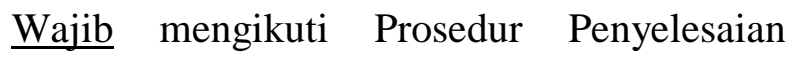
Sengketa melalui Mediasi”

Selanjutnya Pasal 03 ayat 02 Peraturan Mahkamah Agung Republik Indonesia Nomor 1 Tahun 2016 Tentang Prosedur Mediasi Di Pengadilan mengemukakan pula bahwa "Hakim Pemeriksa Perkara dalam pertimbangan putusan wajib menyebutkan bahwa perkara telah diupayakan perdamaian melalui Mediasi dengan menyebutkan nama Mediator".

Bahwa dengan demikian, Majelis Hakim dalam memutuskan perkara yang sama sekali Tidak memberikan kesempatan untuk Melakukan Mediasi / menempuh Prosedur Mediasi sangat jelas telah melakukan Pelanggaran terhadap Ketentuan Pasal 130

HIR dan atau Pasal 154 Rbg yang mengakibatkan Putusan Batal Demi Hukum;

\subsection{Implementasi Peraturan Mahkamah} Agung Republik Indonesia Nomor 1 Tahun 2016 Tentang Prosedur Mediasi di Pengadilan dalam Putusan Pengadilan Agama Rantauprapat No. No.487/Pdt.G/2020/PA-RAP Jo Putusan Pengadilan Tinggi Medan No.73/Pdt.G/2020/PTA-MDN.

Dalam ketentuan Peraturan Mahkamah Agung Republik Indonesia Nomor 01 Tahun 2008 Tentang Prosedur Mediasi Di Pengadilan pada Telah diatur secara tegas dalam ketentuan Pasal 02 ayat 04 yang mana mengemukakan bahwa "Hakim dalam Pertimbangan Putusan perkara Wajib menyebutkan bahwa perkara yang bersangkutan telah diupayakan perdamaian melalui Mediasi dengan menyebutkan nama Mediator untuk perkara yang bersangkutan".

Selanjutnya berdasarkan ketentuan Pasal 03 ayat 1 Peraturan Mahkamah Agung Republik Indonesia Nomor 1 Tahun 2016 Tentang Prosedur Mediasi Di Pengadilan mengemukakan bahwa : "Setiap Hakim, Mediator, Para Pihak dan/atau Kuasa Hukum

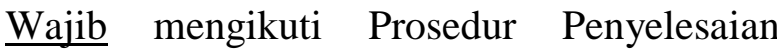
Sengketa melalui Mediasi”

Selanjutnya Pasal 03 ayat 02 Peraturan Mahkamah Agung Republik Indonesia Nomor 1 Tahun 2016 Tentang Prosedur Mediasi Di Pengadilan mengemukakan pula bahwa Jurnal Ilmiah "Advokasi" Vol 08 No. 02 September 2020 
"Hakim Pemeriksa Perkara dalam pertimbangan putusan wajib menyebutkan bahwa perkara telah diupayakan perdamaian melalui Mediasi dengan menyebutkan nama Mediator".

Bahwa dalam prakteknya Majelis Hakim dalam memutuskan perkara pada Pengadilan Agama Rantauprapat No.487/Pdt.G/2020/PARAP yang sama sekali Tidak memberikan kesempatan untuk Melakukan Mediasi / menempuh Prosedur Mediasi sangat jelas telah melakukan Pelanggaran terhadap Ketentuan Pasal 130 HIR dan atau Pasal 154 Rbg yang mengakibatkan Putusan Batal Demi Hukum.

Putusan Hukum Pengadilan Agama Rantauprapat No.487/Pdt.G/2020/PA-RAP Bertanggal 02 April 2020, yang amar putusannya berbunyi sebagai berikut Mengadili dengan Mengabulkan Gugatan Penggugat untuk seluruhnya, Menjatuhkan Talaq Satu Ba'in Sughro Tergugat Terhadap Penggugat serta Membebankan Kepada penggugat untuk membayar biaya perkara sejumlah Rp. 396.000,- (tiga ratus sembilan puluh enam ribu rupiah);

Dalam perjalanannya terhadap putusan sebagaimana yang telah disebutkan diatas termohon (Pembanding) merasa keberatan dan memajukan Memori Banding terhadap Putusan Hukum Pengadilan Agama Rantauprapat No.487/Pdt.G/2020/PA-RAP Bertanggal 02 April 2020.

Bahwa adapun alasan keberatan Pembanding yang dituangkan dalam Memori
Banding Terhadap Putusan Hukum Pengadilan Agama Rantauprapat No.487/Pdt.G/2020/PA$\boldsymbol{R A P}$ Bertanggal 02 April 2020, adalah sebagai berikut :

Bahwa Tergugat/Pembanding tidak sependapat dengan Keputusan Hukum Judex Factie Pengadilan Agama Rantauprapat No.487/Pdt.G/2020/PA-RAP Bertanggal 02 April 2020 yang telah memutuskan perceraian antara Tergugat/Pembanding dengan Penggugat/Terbanding dengan suatu Keputusan Perceraian;

Bahwa Tergugat/Pembanding sangat keberatan terhadap Pertimbangan hukum Keputusan Hukum Judex Factie Pengadilan Agama Rantauprapat No.487/Pdt.G/2020/PA-RAP Bertanggal 02 April 2020 yang menyatakan bahwa dalam Perkara Aquo telah ditempuh Mediasi yang mana sesuai Laporan Mediator M.ARIF SANI SHI Tertanggal 02 April 2020 Ternyata Mediasi tidak Berhasil.

Bahwa Pertimbangan Hukum tersebut diatas adalah Pertimbangan Hukum yang mengada-ada dan terkesan Main Hakim Sendiri, yang mana secara fakta hukum pula Hakim yang memeriksa perkara No.487/Pdt.G/2020/PA-RAP hanyalah berjumlah 1 Orang (Hakim Tunggal) dan tidak sesuai dengan Putusan sebagaimana disebutkan terdapat Hakim Anggota.

Bahwa pada kesempatan ini Tergugat/Pembanding menyampaikan bahwa sidang pertama dilakukan pada Tanggal 02 Jurnal Ilmiah "Advokasi" Vol 08 No. 02 September 2020 
April 2020 dan pada sidang Pertama itu Hakim yang memeriksa Perkara No.487/Pdt.G/2020/PA-RAP langsung memutuskan perkara tersebut tanpa ada sama sekali dilakukan Mediasi sesuai Laporan Mediator Tertanggal 02 April 2020 sebagaimana yang disebutkan dalam Putusan No.487/Pdt.G/2020/PA-RAP Tertanggal 02 April 2020.

Bahwa menurut Pembanding, Majelis Hakim dalam memutuskan perkara No.487/Pdt.G/2020/PA-RAP yang sama sekali Tidak memberikan kesempatan untuk Melakukan Mediasi / menempuh Prosedur Mediasi sangat jelas telah melakukan Pelanggaran terhadap Ketentuan Pasal 130 HIR dan atau Pasal 154 Rbg yang mengakibatkan Putusan Batal Demi Hukum.

Bahwa sesuai dengan Ketentuan Peraturan Mahkamah Agung Republik Indonesia Nomor 01 Tahun 2008 Tentang Prosedur Mediasi Di Pengadilan pada pasal 02 ayat 04 mengemukakan bahwa "Hakim dalam Pertimbangan Putusan perkara Wajib menyebutkan bahwa perkara yang bersangkutan telah diupayakan perdamaian melalui Mediasi dengan menyebutkan nama Mediator untuk perkara yang bersangkutan”.

Selanjutnya berdasarkan ketentuan Pasal 03 ayat 1 Peraturan Mahkamah Agung Republik Indonesia Nomor 1 Tahun 2016 Tentang Prosedur Mediasi Di Pengadilan mengemukakan bahwa : " Setiap Hakim, Mediator, Para Pihak dan/atau Kuasa Hukum
Wajib mengikuti Prosedur Penyelesaian

Sengketa melalui Mediasi”

Selanjutnya Pasal 03 ayat 02 Peraturan Mahkamah Agung Republik Indonesia Nomor 1 Tahun 2016 Tentang Prosedur Mediasi Di Pengadilan mengemukakan pula bahwa "Hakim Pemeriksa Perkara dalam pertimbangan putusan wajib menyebutkan bahwa perkara telah diupayakan perdamaian melalui Mediasi dengan menyebutkan nama Mediator".

Bahwa oleh karenanya, karena Majelis Hakim yang telah memeriksa perkara No.487/Pdt.G/2020/PA-RAP sama sekali tidak memberikan kesempatan kepada Penggugat dan Tergugat (sekarang Pembanding dan Terbanding) untuk dilakukan Mediasi maka sudah sepantasnya Majelis Hakim Pengadilan Tinggi Medan menyatakan bahwa Putusan No.73/Pdt.G/2020/PA-RAP Tertanggal 02 April 2020 Batal Demi Hukum.

Berdasarkan alasan-alasan Memori Banding Tergugat/Pembanding Pengadilan Tinggi Agama Medan, memberikan keputusan dengan:

\section{MENGADILI:}

1. Menerima Permohonan Banding

Tergugat/Pembanding seluruhnya.

2. Membatalkan Keputusan Pengadilan Agama Rantauprapat No.487/Pdt.G/2020/PA-RAP Tertanggal 02 April 2020, yang dimohon Banding. 


\section{MENGADILI SENDIRI :}

1. Menolak Gugatan Penggugat seluruhnya ;

2. Menghukum Penggugat / Terbanding untuk membayar biaya perkara yang timbul dalam perkara ini;

Selanjutnya dalam pertimbangan Majelis Hakim Pengadilan Tinggi Medan yang telah menyatakan bahwa Putusan No.73/Pdt.G/2020/PA-RAP Tertanggal 02 April 2020 Menolak Gugatan Penggugat seluruhnya, sama sekali sebagai landasan hukum pertimbangannya tidak berdasar ketentuan Pasal 03 ayat 1 Peraturan Mahkamah Agung Republik Indonesia Nomor 1 Tahun 2016 Tentang Prosedur Mediasi Di Pengadilan, namun akan tetapi karena kedudukan saksi yang dihadirkan oleh Penggugat adalah saksi yang sama sekali tidak melihat antara Penggugat dan Tergugat bertengkar namun hanya menceritakan cerita dari Penggugat;

\section{KESIMPULAN}

Berdasarkan uraian dari bab-bab sebelumnya, dapat diambil kesimpulan sebagai berikut:

1) Hasil penelitian menunjukkan bahwa ketentuan Peraturan Mahkamah Agung Republik Indonesia Nomor 1 Tahun 2008 dan atau Peraturan Mahkamah Agung Republik Indonesia Nomor 1 Tahun 2016 Tentang Prosedur Mediasi di Pengadilan pada pasal 02 ayat 04 mengemukakan bahwa "Hakim dalam Pertimbangan Putusan perkara Wajib menyebutkan bahwa perkara yang bersangkutan telah diupayakan perdamaian melalui Mediasi dengan menyebutkan nama Mediator untuk perkara yang bersangkutan;

2) Kedudukan Mediasi sebagaimana Peraturan Mahkamah Agung Republik Indonesia Nomor 1 Tahun 2016 adalah salah satu langkah yang harus ditempuh dalam menjalankan sistem Peradilan yang mana berdasarkan Putusan Majelis Hakim Pengadilan Tinggi Medan menyatakan Menolak Gugatan Penggugat seluruhnya dengan Pertimbangan Perkara tersebut telah ditempuh jalur Mediasi walaupun tidak secara maksimal serta pertimbangan hukumnya bahwa kedudukan saksi yang dihadirkan oleh Penggugat adalah saksi yang sama sekali tidak melihat antara Penggugat dan Tergugat bertengkar namun hanya menceritakan cerita dari Penggugat.

\section{Buku}

Munir Fuady, Arbitrase Nasional (Alternatif Penyelesaian Sengketa Bisnis), (Bandung: Citra Aditya Bakti, 2000), hlm. 47.

Muhammad Saifullah, Mediasi Dalam Tinjauan Hukum Islam dan Hukum Positif di Indonesia, (Semarang: Walisongo Press, 2009), hlm. 79.

Moch. Faisal Salam, Penyelesaian Sengketa Bisnis Secara Nasional Dan Internasional, (Bandung: Mandar Maju, 2007), hlm. 221. 
M. Yahya Harahap, Hukum Acara Perdata, (Jakarta: Sinar Grafika, 2008), hlm. 265.

Buku Tanya Jawab Perma RI No. 1 tahun 2008 tentang Prosedur Mediasi di Pengadilan, (kerjasama atas Mahkamah Agung RI, JICA, IICT 2008).

Syahrial Abbas, Mediasi Dalam Perspektif Hukum Syari'ah, Hukum Adat, dan Hukum Nasional, (Jakarta: Kencana, 2009), hlm. 6-7.

Gunawan Widjaja, Alternatif Penyelesaian Sengketa, (Jakarta: Raja Grafindo Persada, 2001), hlm. 91.

Musahadi, Mediasi dan Resolusi Konflik di Indonesia, (Semarang: Walisongo Mediation Center, 2007), hlm. 84.

\section{Peraturan Perundang-Undangan;}

Peraturan Mahkamah Agung Republik Indonesia Nomor 01 Tahun 2008 Tentang Prosedur Mediasi;

Peraturan Mahkamah Agung Republik Indonesia Nomor 1 Tahun 2016 Tentang Prosedur Mediasi Di Pengadilan

\section{Putusan :}

Putusan Pengadilan Agama Rantauprapat No. 487/Pdt.G/2020/PA.RAP; 